JURNAL DAKWAH DAN KOMUNIKASI

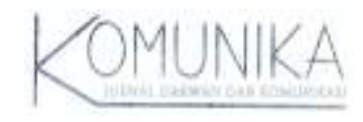

\title{
MARKETING POLITIK DI MEDIA MASSA DALAM PEMILU 2009
}

\author{
Gun Gun Heryanto"
}

\begin{abstract}
"Penulis adalah dosen tetap Fakultas Dakwah UIN Syarif Hidayatullah Jakarta, dan sedang menyelesaikan program S3 di Universitas Padjajaran Bandung.
\end{abstract}

Abstract: The phenomena of general election in 2009 shows that political marketing is an important part of winning the competition. This marketing approach has been transparently used since 1999 and continued to 2004. However, its more intensive use could be seen in the last general election in 2009. It was probably the era of an image industry which force an individual and a party to construct their best image in mass media. The more democracy following the fall of New Order enables all political power to compete fairly. This condition is in line with the wind of press independence which grows as a developing industry. In relation to the general election, mass media can be synergetic with political agents or the candidates. For the media, politics is considered as a product or service which has a high economical value; and for the politicians, mass media is a means of political communication to raise their popularity. Keywords: general election 2009, marketing, politics, mass media, Setting agenda theory, spiral of silence theory.

\section{PENDAHULUAN}

Marketing politik dalam Pemilihan Umum (pemilu) memainkan peran yang sangat penting karena merupakan bagian dari aktivitas persuasi. Kampanye mengemas pesan politik secara intensif dalam kurun waktu tertentu yang dibatasi, guna mendapatkan pengaruh di kalangan khalayak politik. Dengan harapan, khalayak mendukung dan menjatuhkan pilihan pada kandidat yang mengkampanyekan diri tersebut.

Satu fenomena yang menonjol dalam pemilu 2009 adalah semakin kuatnya peranan media massa di Indonesia dalam proses konstruksi citra para kandidat, baik perseorangan (caleg, capres, dan cawapres) maupun organisasi partai politik. Pemanfaatan media untuk mendongkrak popularitas sebenarnya telah mulai marak dan bebas sejak pemilu 1999, dan semakin menguat di pemilu 2004 hingga pemilu kali ini. Bisa kita katakan, kemenangan SBY pada pemilihan presiden secara langsung pemilu lalu, merupakan keberhasilan marketing politiknya karena partainya sendiri bukanlah partai pemenang pemilu. Pada pemilu 2009, masa kampanye diperpanjang menjadi 9 bulan dimulai 12 Juli 2008 - April 2009. Dengan 38 partai peserta pemilu, dan banyaknya tokoh yang menyatakan diri siap menjadi kandidat presiden dan wakil presiden, tentunya kian meramaikan "pertarungan citra" dalam merebut hati para pemilih. Kandidat yang menguasai industri citra tentunya akan memperbesar peluangnya memenangkan pertarungan tersebut.

Hanya saja, untuk memahami peran media massa dalam pemilu ini sangat tergantung pada perspektif teori yang digunakan. Dalam makalah ini, kami bermaksud menganalisis fenomena marketing politik di media massa dalam pemilu 2009 dilihat dari tiga teori komunikasi massa yakni: Teori Agenda Setting, Teori Kultivasi dan Teori Spiral of Silence.

\section{FENOMENA PEMILU 2009}

Fenomena yang menonjol dari pemilu 2009 ialah semakin intensifnya partai politik, Calon Anggota Legislatif(caleg), dan kandidat capres serta cawapres mengiklankan diri di berbagai media massa. Namun, yang paling menonjol dari sekian tampilan iklan di berbagai media itu, tampaknya iklan Partai Demokrat, Golkar, PDIP, PKS, PAN, Partai Gerindra, dan 


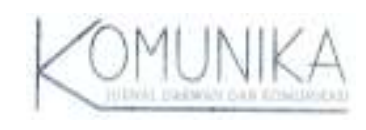

Hanura-lah yang banyak diperbincangkan, baik dari segi isi iklan juga dari segi anggaran biaya yang disinyalir berjumlah sangat besar untuk ukuran marketing politik di Indonesia. Hal ini terbukti dari masuknya partai-partai tersebut dalam 10 besar partai pemenang Pemilu.

Lima target bidikan waktu penting dalam pemilu 2009 tentu telah dihitung dan dianalisis secara seksama.

a. Pada 9April, pemungutan suara untuk pemilu legislatif, baik di level DPR, DPRD, dan DPD.

b. Pada 8Juli, perebutan kursi presiden dan wakil presiden putaran pertama.

c. Pada 21 September, putaran kedua pemilihan presiden dan wakil presiden jika diperlukan karena dengan banyaknya kandidat, sepertinya tidak mungkin cukup 1 putaran.

d. Pada 1 Oktober, mereka yang menjadi pemenang dalam pemilu legislatif, dan akan dilantik sebagai anggota DPR.

e. pada 20 Oktober merupakan jadwal pelantikan presiden dan wakil presiden terpilih.

Selain target bidikan waktu tadi, jumlah kursi yang tersedia pun menjadi bahan berhitung dalam konstelasi politik yang berkembang. Perang terbuka diprediksi akan berjalan sengit karena pemilu langsung menyediakan jumlah kursi yang terbatas. Sebanyak 18.442 kursi akan diperebutkan oleh para kandidat yang namanya telah masuk di Daftar Calon Tetap, rinciannya:

a. 15.750 kursi DPRD kota/kabupaten.

b. 1.998 kursi DPRD provinsi.

c. 560 kursi DPR.

d. 132 kursi DPD.

Begitu pun menyangkut pemimpin negeri ini, hanya sepasang saja yang nantinya dipilih. Wilayah perebutan kekuasaan tadi mendorong seluruh kandidat untuk all out menyambut tahun baru 2009 dengan berbagai amunisi perang citra.

Hasil rapat koordinasi antara KPU dan Depdagri menyimpulkan terjadi penambahan jumlah penduduk 1,2 juta jiwa dalam data kependudukan yang diserahkan oleh pemerintah. Data tersebut akan terus di-up date untuk menyusun data pemilih pemilu 2009. Koordinator Pokja Pemutakhiran Data Pemilih KPU, Sri Nuryanti, mengatakan telah disepakati jumlah penduduk di 33 provinsi dan 471 kabupaten/kota dan 6.093 kecamatan mencapai 225.324.780 jiwa. Jumlah ini meningkat 1.206.512 orang bila dibanding dengan data pada 5 April 2008. Ketika itu, data penduduk dalam negeri yang diserahkan pemerintah sebanyak 224. 118.268 orang. Data penduduk potensial pemilih 154.741.787jiwa (Media Indonesia, Selasa, 22/4). Oleh karena itu, ke-38 partai politik, ribuan calon anggota legislatif serta semua pasangan capres dan cawapres ini harus meyakinkan khalayak pemilih bahwa mereka benar-benar layak dipertimbangkan sebagai kandidat yang pantas. Dalam konteks itulah, pendekatan marketing politik memiliki fungsi yang strategis.

\section{KONSEPTUALISASI MARKETINGPOLITIK}

Marketing, menurut Bruce I Newman, adalah proses memilih customer, menganalisis kebutuhan mereka, dan kemudian mengembangkan inovasi produk, advertising, harga, dan strategi distribusi dalam basis informasi. Marketing, dalam pengertian Bruce, bukan dalam pengertian marketing biasa, melainkan produk politik berupa image politisi, platform, pesan politik, dan lain-lain yang dikirim ke audiens yang diharapkan menjadi konsumen yang tepat. ${ }^{1}$

Pendapat lain dikemukakan oleh Mauser G. yang mendifinisikan marketing sebagai 'influencing mass behavior in competitive situations ${ }^{2}$. Marketing politik dianalogikan kepada marketing komersial. Misalnya, di sektor komersial harus memiliki target audience dari pemilih yang harusnya mendukung, menggunakan media massa, dalam sebuah lingkungan kompetitif yang dipadati lebih dari satu 'brand' produk. Dalam hal ini, ada perbedaan mendasar antara marketing politik dengan marketing komersial. Misalnya, marketing politik mengukur kesuksesan tidak dalam term keuntungan, melainkan dalam hasil voting dan efektivitas power. ${ }^{3}$

Dalam bukunya, Hand Book of Political Marketing, Newman menambahkan dalam peta marketing kandidat (Candidat Marketing Map) paling tidak ada enam tahapyang harus diperhatikan. ${ }^{4}$ 
1. Riset lingkungan (environment research), yakni setting dan konteks di mana seorang kandidat mengorganisasikan sebuah kampanye. Hal ini terkait dengan upaya mendifinisikan isu, peluang, dan tantangan yang dihadapi kandidat. Misalnya, pada tahap ini, meriset situasi ekonomi, mood pemilih (voter satisfaction or dissatisfaction), isu dan konsern penting pemilih, peta demografi pemilih, riset partai dominan atau independen, dan sebagainya.

2. Analisis penilaian internal dan eksternal (internal and external assesment analysis). Kandidat mesti menilai kekuatan dan kelemahan dirinya, kekuatan dan kelemahan organisasi kampanye pada seluruh tahapan pengembangan, status kandidat sebagai incumbent atau penantang, peluang isu-isu kampanye, dan kekuatan dan kelemahan kompetitor.

3. Marketing strategis (strategic marketing), misalnya terkait dengan segmentasi pemilih (usia, income, pendidikan, etnis, ideologi kelompok, dan sebagainya.), target, dan positioning (citra kandidat versus citra lawan).

4. Setting tujuan dan strategi kampanye (goal setting and campaign strategy), misalnya menyangkut positioning latarbelakang dan qualifikasi, pesan utama kampanye, pemilihan isu dan solusi konsep pribadi kandidat, dan sebagainya.

5. Komunikasi, distribusi, dan perencanaan organisasi (communication, distribution, and organization plan). Tahap ini, misalnya menekankan pada sosok penampilan, publisitas, iklan dan pemilihan pesan, format, serta desain medianya. Termasuk penyiapan organisasinya, misalnya saja, fundraiser and development staff, Issue and Research Staff, Media and Publicity Staff, Voulenteers and Party Workers, dan sebagainya.

6. Pasar-pasar (massa) utama dan hasil (key markets and outcomes) yang terkait dengan segmen konstituen pemilih partai, segmen kontributor, segmen media, dan publisitas.

Di dalam tulisan lainnya, Newman menulis tentang formula kesuksesan marketing politik yang mestinya mengikuti beberapa aturan dasar. Pertama, menyediakan waktu yang banyak untuk mempelajari kebutuhan dari target customers. Kedua, membuat team pengembangan customer. Ketiga, mendapatkan dukungan dari seseorang yang berkedudukan tinggi di organisasi dan orang yang siap menjadi pembela, menyediakan banyak waktu untuk mengumumkan produk baru, dan kesuksesan pengembangan produk baru meminta organisasi untuk memapankan sebuah organisasi yang efektif dalam menangani proses pengembangannya. ${ }^{5}$

Dalam praktik pemilu 2009, marketing politik dapat kita amati dalam proses kampanye politik, baik melalui media lini atas (above line media), media lini bawah (below line media), maupun pendekatan media baru (new media campaign). Beragam aktivitasnya, misalnya iklan politik, publisitas, public relations, dan sebagainya. Menurut Roger dan Storey, kampanye merupakan serangkaian tindakan komunikasi yang terencana dengan tujuan menciptakan efek tertentu pada sejumlah besar khalayakyang dilakukan secara berkelanjutan pada kurun waktu tertentu. ${ }^{6}$

Dalam definisi lainnya, Pfau dan Parrot mendefinisikan kampanye sebagai "A Campaign is conscious, sustained and incremental process designed to be implemented over a specified period of time for the purpose of influencing a specified audience (kampanye adalah suatu proses yang dirancang secara sadar, bertahap, dan berkelanjutan yang dilaksanakan pada rentang waktu tertentu dengan tujuan mempengaruhi khalayak sasaran yang telah ditetapkan).7

\section{MEDIA MASSA SEBAGAI SALURAN MARKETINGPOLITIK}

Kalau merujuk kepada pendapat Blumler dan Gurevitch, ada empat komponen yang perlu diperhatikan dalam mengkaji sistem komunikasi politik. Pertama, institusi politik dengan aspek-aspek komunikasi politiknya. Kecha, institusi media dengan aspek-aspek komunikasi politiknya. Ketiga, orientasi khalayak terhadap komunikasi politik. Keempat, aspek-aspek komunikasi yang relevan dengan budaya politik. ${ }^{8}$

Pendapat hampir senada dikemukakan Suryadi, menurutnya, sistem komunikasi politik terdiri dari elite politik, media massa, dan khalayak. Dari kedua pendapat tadi, dapat kita temui posisi penting media dalam marketing politik. Setiap persuasi politik yang mencoba memanipulasi psikologis khalayak sekarang ini, sangat mempertimbangkan peranan media massa. ${ }^{9}$ 


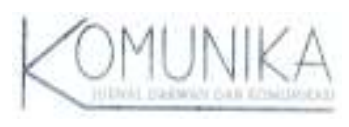

Untuk memperkuat argumen bahwa media sangat penting dalam proses marketing politik, baiknya kita memahami dulu karakteristik media massa. Media massa merupakan jenis media yang ditunjukkan kepada sejumlah khalayak yang tersebar, heterogen, dan anonim sehingga pesan yang sama dapat diterima secara serentak dan sesaat.

Perkataan "dapat" menjadi sangat rasional karena seperti dikatakan Alexis S.Tan, komunikator dalam media massa ini merupakan suatu organisasi sosial yang mampu memproduksi pesan dan mengirimkannya secara simultan kepada sejumlah besar masyarakat yang secara spasial terpisah..$^{10}$

Dengan daya jangkau yang relatif luas dan dalam waktu yang serentak, media massa mampu memainkan peran dalam propaganda. Relevan dengan pendapat Cassata dan Asante, seperti dikutip Jalaluddin Rakhmat, bila arus komunikasi massa ini hanya dikendalikan oleh komunikator, situasi dapat menunjang persuasi yang efektif. Sebaliknya, bila khalayak dapat mengatur arus informasi, situasi komunikasi akan mendorong belajaryang efektif."

Dalam konteks era informasi sekarang ini, institusi media massa seperti televisi dan surat kabar dipercaya memiliki kemampuan dalam menyelenggarakan produksi, reproduksi, dan distribusi pengetahuan secara signifikan. Serangkaian simbol yang memberikan makna tentang realitas "ada" dan pengalaman dalam kehidupan bisa ditransformasikan media massa dalam lingkungan publik sehingga bisa diakses anggota masyarakat secara luas.

Tentu saja, dalam perkembangnnya, banyak pihak yang terlibat dalam pemanfaatan media massa sebagai instrumen pemenuhan kepentingannya. Sebut saja negara (state), pasar (market), kelompok kepentingan (interest group), kelompok penekan (pressure group), dan sebagainya.

Proses marketing politik di era sekarang sangat sulit menafikan keberadaan media massa sebagai salah satu saluran utama yang dapat dipergunakan dalam komunikasi politik. Saluran media massa ini memegang posisi penting di luar saluran face-to-face informal, struktur sosial tradisional, saluran input, dan saluran out put.

\section{ANALISIS: PERSPEKTIF TEORI AGENDA SET'TING}

Teori Agenda Setting diperkenalkan oleh Maxwell McCombs dan Donald L. Shaw dalam tulisan mereka yang berjudul "The Agenda Setting Function of Mass Media” yang telah diterbitkan dalam Public Opinion Quarterly pada tahun 1972. Menurut kedua pakar ini, jika media memberikan tekanan pada suatu peristiwa, maka media itu akan mempengaruhi khalayak untuk menganggapnya penting. ${ }^{12}$

Agenda Setting menggambarkan pengaruh yang kuat dari media, terutama kemampuannya untuk mengatakan isu apa yang penting dan tidak. McComb dan Shaw menyelidiki kampanye presiden di tahun 1968, 1972, dan 1976. Dalam risetnya tahun 1968, mereka fokus pada dua elemen pokok, yakni kesadaran dan informasi. Dalam riset empiris di sebuah wilayah di Chapel Hill North Caroline. Saat itu, riset men-survey 100 orang pemilih yang belum memutuskan pilihan tentang apa yang mereka pikirkan di tengah berita aktual yang dipublikasikan media. Studi tersebut menemukan bukti bahwa terdapat korelasi yang sangat kuat $(0,975)$ antara urutan prioritas pentingnya 5 isu yang dilansir oleh media di Chapel Hill dengan urutan prioritas pada responden. Hasil yang hampir identik dan cocok dengan hipotesis mereka bahwa media massa memosisikan agenda opini publik dengan penekanan topik-topik tertentu yang khusus. Alexis S. Tan meyimpulkan bahwa dalam Teori Agenda Setting, meningkatnya nilai penting suatu topik pada media massa menyebabkan meningkatnya nilai penting topik tersebut pada khalayak. ${ }^{13}$

Dengan teknik pemilihan dan penonjolan, media memberikan petunjuk tentang mana issue yang lebih penting. Oleh karena itu, model agenda setting mengasumsikan adanya hubungan positif antara penilaian yang diberikan media kepada suatu persoalan dengan perhatian, yang diberikan khalayak kepada persoalan itu. Singkatnya, sesuatu yang dianggap penting oleh media, akan dianggap penting pula oleh masyarakat. Begitu juga sebaliknya, sesuatu yang dilupakan media, akan luput juga dari perhatian masyarakat.

Sementara itu, Manhein sebagaimana dikutip oleh Effendy menyatakan bahwa terdapat konseptualisasi agenda yang potensial untuk memahami proses agenda setting, yakni agenda media, agenda khalayak, dan agenda kebijakan. Masing- 


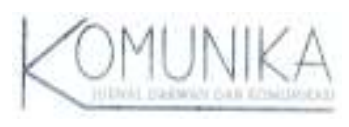

masing agenda tersebut mencakup dimensi-dimensi sebagai berikut, ${ }^{4}$ pertama, untuk agenda media, yang dimensidimensinya:

a. Visibility (visibilitas), yakni jumlah dan tingkat menonjolnya berita.

b. Audience salience (tingkat menonjolnya bagi khalayak), yakni relevansi isi berita dengan kebutuhan khalayak.

c. Valence (valensi), yakni menyenangkan atau tidak menyenangkan cara pemberitaan bagi suatu peristiwa.

Kedua, agenda khalayak, adapun dimensi-dimensi yang biasanya ada dalam agenda khalayak:

a. Familiarity (keakraban), yakni derajat kesadaran khalayak akan topik tertentu.

b. Personal Salience (penonjolan pribadi), yakni relevensi kepentingan dengan ciri pribadi.

c. Favorability (Kesenangan), yakni pertimbangan senang atau tidak senang akan topik berita.

Ketiga, agenda kebijakan, adapun dimensi-dimensi yang biasanya ada dalam agenda kebijakan:

a. Support (dukungan), yakni kegiatan menyenangkan bagi posisi berita tertentu.

b. Likelihood of action (kemungkinan kegiatan) kemungkinan pemerintah melaksanakan sesuatu yang diibaratkan.

c. Freedom of action (kebebasan bertindak), yakni nilai kegiatan yang mungkin dilakukan pemerintah.

Marketing politik di media massa, tentunya, tidak lepas dari pembicaraan soal efek karena merupakan entry point bahasan agenda setting. Komunikator politik yang hendak menggunakan media massa sebagai medium penyampaian pesan politik sudah seharusnya memahami masalah efek ini. Efek terdiri dari efek langsung dan efek lanjutan (subsequent effects). Efek langsung ini berkaitan dengan issues, apakah issue itu ada atau tidak ada dalam agenda khalayak (pengenalan); dari semua issues, mana yang dianggap paling penting menurut khalayak (salience); bagaimana issues itu di-ranking oleh responden dan apakah rangking-nya itu sesuai dengan rangking media?

Efek lanjutan berupa persepsi (pengetahuan tentang peristiwa tertentu) atau tindakan (seperti memilih kontestan atau kandidat dalam Pemilu). Pada kenyataannya, menurut perspektif teori agenda setting, media massa menyaring artikel, berita, atau acara yang disiarkannya. Secara selektif, "gatekeepers" seperti penyunting, redaksi, bahkan wartawan sendiri menentukan peristiwa manayang pantas diberitakan dan mana yang harus disembunyikan.

Yang menarik dicermati, karena pembicara, pemirsa, dan pendengar memperoleh kebanyakan informasi melalui media massa, maka agenda media tentu berkaitan dengan agenda masyarakat (public agenda). Agenda masyarakat diketahui dengan menanyakan kepada anggota masyarakat apa yang mereka pikirkan dan bicarakan dengan orang lain, atau apa yang mereka anggap sebagai masalah yang tengah menarik perhatian masyarakat (community salience).

Masyarakat tentunya memiliki hak untuk tahu (right to know) yang akhirnya menjadikan isu atau peristiwa menjadi public sought (permintaan publik) akan informasi tentang isu atau peristiwa tersebut. Media dengan kepentingan teknis, idealisme, dan pragmatismenya memilih, mengemas, dan akhirnya mendistribusiakan kepada khalayak kalau sesuatu itu penting.

Relevan dalam konteks ini, media melakukan pengemasan (framing). Membuat frame berarti menyeleksi beberapa aspek dari pemahaman atas realitas dan membuatnya lebih menonjol. Esensinya dilakukan dengan berbagai cara, antara lain penempatan (kontekstualisasi), pengulangan, asosiasi terhadap simbol budaya, generalisasi, simplikasi, dan sebagainya. Framing merupakan cara bercerita yang menghadirkan konstruksi makna atas peristiwa-peristiwa yang berkaitan dengan objek suatu wacana.

Suatu upaya persuasif dalam kemasan marketing politik di media massa, dari perspektif agenda setting, tentunya harus memperhatikan beberapa hal pokok. Pertama, struktur makro, artinya makna umum dari suatu tampilan marketing politik di media yang dapat diamati dengan melihat topik atau tema yang dikedepankan. Kedua, superstruktur, yang merupakan struktur marketing politik yang berhubungan dengan kerangka suatu teks, yakni mengenai cara bagian-bagian teks atau acara yang dibuat dan diarahkan kepada khalayak tersusun secara utuh.

Ketiga, struktur mikro, ini merupakan marketing politik yang dapat diamati melalui bagian kecil dari suatu teks atau acara di media massa. Kalau dalam wujud teks, misalnya kata, kalimat, proposisi, anak kalimat, atau gambar, dan angel pengambilan photo suatu kejadian. Hal-hal yang diamati dalam struktur mikro, misalnya meliputi semantik, yaitu bentuk 


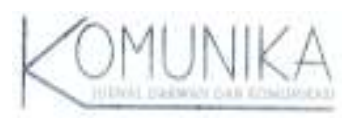

susunan kalimat yang dipilih. Stilistik, yaitu pilihan kata yang dipakai dalam teks berita, dan retoris, yaitu cara penekanan itu dilakukan. Marketing politik dalam media massa tentu saja berbeda dengan marketing yang dilakukan lewat model rapat akbar partai dan ceramah di lapangan. Marketing di media sangat dibatasi dengan waktu atau space yang disediakan. Oleh karena itu, kemampuan pengemasan menjadi hal yang sangat pokok.

Dari perspektif agenda setting, media massa memang tidak dapat mempengaruhi orang untuk mengubah sikap, tetapi media massa cukup berpengaruh terhadap hal-hal yang dipikirkan orang. Ini berarti media massa mempengaruhi persepsi khalayak tentang apa yang anggap penting. Bila Prabowo dan Partai Gerindra secara terus-menerus diberi label penolong serta pelindung para petani dan pedagang tradisional, maka lambat laun Prabowo akan dianggap dalam persepsi khalayak sebagai penolong dan pelindung wong cilik. Iklan Prabowo dalam berbagai versi di televisi ternyata mampu menaikan tingkat penerimaan khalayak akan sosok Prabowo dan Partai Gerindra. Berkat iklannya yang terus-menerus di berbagai televisi, menurut hasil Survey Lembaga Survey Nasional (LSN) pada 20-27 September 2008, menunjukkan tingkat elektabilitas pemilih menjadi 14, 2 persen. Dengan demikian, dia menempati posisi ketiga setelah SBY dengan tingkat elektabilitas 30 persen dan Megawati 15,3 persen. Hasil survey terhadap 400 responden di 15 kota tersebut menunjukkan alasan mereka tertarik kepada Prabowo, jawabannya ternyata 79,9 persen responden menyatakan mereka tertarik karena iklan Probowo yang simpatik dengan pesan-pesan mewakili para petani, nelayan, dan pedagang pasar tradisional..$^{15}$ Ini menunjukkan hal penting bahwa jika media selalu mengangkat citra Prabowo yang dekat dengan kaum petani nelayan dan pedagang pasar tradisional, maka pemilih pun akan memikirkan bahwa Prabowo sebagai sosok yang penting sebagaimana yang dicitrakan oleh media.

Kita juga perlu mengkritisi perspektif agenda setting dalam menganalisis marketing politik di media massa. Agenda setting memandang media massa melakukan "to tell what to think about". Artinya, membentuk persepsi khalayak tentang apa yang dianggap penting. Dalam konteks ini, perlu dipertanyakan, apakah penilaian khalayak tentang suatu isu atau pesan marekting yang dianggap penting itu karena penonjolan yang dilakukan oleh media atau karena faktor-faktor lain? Pertanyaan tersebut muncul karena dalam realitasnya, seringkali cara pandang seseorang mengenai pemahaman terhadap pesan politik-sebelumnya sudah terbentuk melalui pengaruh interpersonal, melalui interaksi di organisasi-dalam norma kelompok atau melalui pemuka pendapat melaluijalinan komunikasi two-stepflow-communication.

\section{ANALISIS PERSPEKTIF TEORI SPIRAL OF SILENCE}

Elizabeth Noelle-Neumann (seorang professor emeritus penelitian komunikasi dari Institute fur Publiziztik Jerman) adalah orang yang memperkenalkan teori spiral keheningan/kesunyian ini. Teori ini diperkenalkan pertama kali pada tahun 1984 melalui tulisannya yang berjudul The Spiral of Silence. Secara ringkas, teori ini ingin menjawab pertanyaan, mengapa orang-orang dari kelompok minoritas sering merasa perlu untuk menyembunyikan pendapat dan pandangannya ketika berada dalam kelompok mayoritas? Dengan kata lain, bisa dikatakan bahwa seseorang sering merasa perlu menyembunyikan "sesuatu"-nya ketika berada dalam kelompok mayoritas.

Ide terpenting yang mendasari model ini adalah sebagian besar individu mencoba menghindari isolasi dalam pengertian sendirian mempunyai kepercayaan atau sikap tertentu. Oleh karenanya, seseorang memperhatikan lingkungannya dalam rangka mempelajari pandangan mana yang semakin kuat, dan yang mana semakin tidak popular.

Tesis teori ini bersandar pada dua asumsi. Pertama, bahwa orang mengetahui opini yang berkembang dan yang tidak berkembang. Hal ini disebut quasi-statistical sense karena orang mempunyai perasaan terhadap persentase penduduk untuk dan terhadap posisi-posisi tertentu. Kedua, orang menyesuaikan pengungkapan opini mereka terhadap persepsi-persepsi ini. ${ }^{16}$

Teori Spiral Keheningan ini dapat diuraikan sebagai berikut: individu memiliki opini tentang berbagai isu. Akan tetapi, ketakutan akan terisolasi menentukan apakah individu itu akan mengekspresikan opini-opininya secara umum. Untuk meminimalkan kemungkinan terisolasi, individu-individu itu mencari dukungan bagi opini mereka dari lingkungannya, terutama dari media massa. 
Sprial kesunyian tampaknya disebabkan oleh ketakutan terhadap keterasingan. Seperti yang dinyatakan oleh NoelleNueman, "berjalan bersama dengan kelompok adalah keadaan yang membahagiakan, tetapi jika hal ini tidak dapat dilakukan karena Anda tidak akan sependapat dengan keyakinan yang dinyatakan secara umum, paling tidak Anda akan diam sebagai pilihan kedua sehingga orang lain akan bersama Anda". ${ }^{17}$ Dengan demikian, dapat kita nyatakan bahwa spiral kesunyian bukan sekadar keinginan berada pada pihak yang menang, melainkan merupakan usaha untuk menghindari keterasingan dari kelompok sosial. Spiral keheningan mengajak kita kembali kepada teori media massa yang perkasa, yang mempengaruhi hampir setiap orang dengan cara yang sama.

Noelle-Newman (1984) menyatakan bahwa kekuatan media massa diperoleh dari: (1) kehadirannya di mana-mana (ubiquity); (2) pengulangan pesan yang sama dalam suatu waktu (kumulasi); dan (3) konsensus tentang nilai-nilai di antara mereka yang bekerja dalam media massa, yang kemudian direfleksikan dalam isi media massa.

Dalam marketing Pemilu 2009, tampak sebuah perubahan mendasar seperti yang dilakukan PKS. Tema iklan-iklan PKS cenderung semakin menyesuaikan dengan opini mayoritas di Indonesia. Jika kita perhatikan, sewaktu PKS pertama kali menjadi partai (saat itu bernama PK), jargon-jargon iklannya sangat terbatas, bahkan terkesan eksklusif, misalnya tentang memperjuangan Syari’h atau ajakan untuk masuk ke dalam Islam secara kaffah (sebuah jargon yang kerap ditafsirkan oleh sebagian organisasi Islam lainnya sebagai semangat untuk menjalani Islam secara paripurna termasuk upaya mendirikan negara Islam). Dalam pemilu 1999, suara PKS tidak signifikan, bahkan untuk dapat menjadi peserta pemilu 2004, PK harus berganti nama dan logo karena tidak lolos electoral threshold. Berbagai jargon yang kurang diminati oleh opini mayoritas ini tentu saja membuat PKS memberlakukan penyesuaian-penyesuaian. Dia mencoba untuk meminimalkan kemungkinan terisolasi, individu-individu di PKS mencari dukungan bagi opini mereka dari lingkungannya, terutama dari media massa. PKS dalam Pemilu 2009 memerhatikan lingkungannya dalam rangka mempelajari pandangan yang semakin kuat dan yang semakin tidak popular. Bukti perubahan tersebut, misalnya iklan PKS di pemilu 2009 menampilkan wajah nasionalisnya yang lebih kental. Misalnya, iklan versi Hari Pahlawan, iklan versi Hari Ibu, juga iklan versi Soeharto. PKS sengaja tidak terlampau menunjukkan pandangan keIslamannya yang kental karena mereka menyadari jargon-jargon Islam yang eksklusif tidaklah relevan dengan opini mayoritas Bangsa Indonesia, meski penduduk terbesar Indonesia adalah muslim.

\section{PENUTUP}

Pendekatan marketing politik dalam pemilu 2009 akan semakin intensif karena dukungan media massa. Saat ini, industri media di Indonesia sangat maju pesat sehingga memungkinkan digunakan secara intensif dalam marketing politik para kandidat, baik perseorangan maupun kelompok. Kedua teori yang dibahas di atas tentunya memiliki cara pandang masing-masing dalam melihat fenomena ini. Teori Agenda Setting lebih melihat bahwa media mampu menonjolkan hal-hal yang nantinya juga akan dianggap penting oleh khalayak. Teori Kultivasi melihat bahwa terpaan media massa termasuk marketing melalui media akan mampu menanamkan sikap dan nilai tertentu pada khalayak. Sementara itu, Teori Spiral of Silence menunjukkan seseorang akan memerhatikan lingkungannya dalam rangka mempelajari pandangan mana yang semakin kuat dan yang mana semakin tidak popular. Pandangan minoritas biasanya menyesuaikan diri dengan opini publik yang berkembang. Media massa biasanya menjadi berpengaruh dalam pembentukan opini publik tersebut. Dengan demikian, ketiga teori tersebut, cukup bisa menjelaskan realitas marketing politik partai-partai politik dalam perhelatan demokrasi 2009.

\section{ENDNOTE}

${ }_{1}^{1}$ Bruce Newman, The Mass Marketing of Politics Democracy in An Age of Manufactured Images (London, New Delhi: Sage Publications, 1999), hal. 3.

${ }^{2}$ G. Mauser, Political Marketing: An Approach to Campaign Strategy (New York: Praeger, 1983), hal. 5.

${ }^{3}$ Ibid., hal. 5. 
${ }^{4}$ Bruce Newman (Ed.), Handbook of Political Marketing (London: Sage Publication Inc., 1999), hal. 6-10.

${ }^{5}$ Bruce I. Newman and Perloff, Richard M, "Political Marketing: Theory, Research and Applications", in Kaid, Lynda Lee, Handbook of Political Communications Research (London: Lawrence Erlbaum Associates Publisher, 2004), hal. 24.

${ }^{6}$ EM. Roger \& Storey J.D. Communication Campaign. In C.R. Berger \& S.H Chaffee (Ed.), Handbook of Communications Science (New Burry Park, CA: Sage, 1987).

${ }^{7}$ Michael Pfau \& Roxanne Parrot, Persuasive Communication Campaign (Massachussets: Allyn and Bacon, 1993).

8 Jay G. Blumler and Gurevitch Michael, The Crisis of Public Communication(London and New York: Routledge, 1995), hal. 46.

${ }^{9}$ Syamsu Suryadi, "Elit Politik dalam Komunikasi Politik di Indonesia”, dalam Maswadi Rauf dan Mappa Nasrun, Indonesia dan Komunikasi Politik (Jakarta: Gramedia, 1993), hal. 23.

${ }^{10}$ Alexis S. Tan, Mass Communication Theories and Research (Ohio: Grid Publising, Inc, 1981), hal. 56.

${ }^{11}$ Jalaluddin Rakhmat, Psikologi Komunikasi (Bandung: Remaja Rosdakarya, 1994), hal. 56.

${ }^{12}$ Onong Uchjana Effendy, IImu, Teori dan Filsafat Komunikasi (Bandung: PT. Citra Aditya Bakti, 2003), hal. 287.

${ }^{13}$ Alexis S. Tan, Mass Communication, hal. 277.

${ }^{14}$ Onong Uchjana Effendy, Ilmu teori, hal. 288-289.

${ }^{15}$ uww.detik.com, diakses pada Kamis, 09 Oktober 2008.

${ }^{16}$ Henu Puji Winarso, Sosiologi Komunikasi Massa (Jakarta: Prestasi Pustaka Publisher, 2005), hal. 93.

${ }_{17}$ Ibid., hal. 94.

\section{DAFTAR PUSTAKA}

Blumler, Jay G. and Gurevitch, Michael. 1995. The Crisis of Public Communication. London and New York: Routledge. Effendy, Onong Uchjana. 2003. Ilmu, Teori dan Filsafat Komunikasi. Bandung: PT. Citra Aditya Bakti.

Roger, EM \& Storey J.D. 1987. "Communication Campaign. In C.R. Berger \& S.H Chaffee (Ed.)," dalam Handbook of Communications Science. New Burry Park, CA: Sage.

Kaid, Lynda Lee. 2004. Handbook of Political Communications Research. London: Lawrence Erlbaum Associates Publisher.

Mauser, G. 1983. Political Marketing: An Approach to Campaign Strategy. New York: Praeger.

Newman, Bruce. 1999. The Mass Marketing of Politics Democracy in An Age of Manufactured Images. London, New Delhi: Sage Publications . Bruce I (Ed.). 1999. Handbook of Political Marketing. London: Sage Publication Inchal.

. Bruce I and Perloff, Richard M. 1993. "Political Marketing: Theory, Research and Applications", dalam Pfau, Michael \& Roxanne Parrot.

Persuasive Communication Campaign, Massachussets: Allyn and Bacon.

Rakhmat, Jalaluddin. 1994. Psikologi Komunikasi. Bandung: Remaja Rosdakarya

Rauf, Maswadi dan Mappa Nasrun. TT. Indonesia dan Komunikasi Politik. Jakarta: Gramedia.

Suryadi, Syamsu. 1993. Elit Politik dalam Komunikasi Politik di Indonesia.

Tan, Alexis S. 1981. Mass Communication Theories and Research. Columbus, Ohio: Grid Publishing Inc.

Winarso, Henu Puji. 2005. Sosiologi Komunikasi Massa. Jakarta: Prestasi Pustaka Publisher.

unw.detik.com 